\title{
DESIGN, SYNTHESIS AND CYTOTOXICITY STUDIES OF DITHIOCARBAMATE ESTER DERIVATIVES OF EMETINE IN PROSTATE CANCER CELL LINES.
}

Emmanuel S. Akinboye, ${ }^{\mathrm{a}}$ Zebalda D. Bamji, ${ }^{\mathrm{b}}$ Bernard Kwabi-Addo, ${ }^{\mathrm{b}}$ David Ejeh, ${ }^{\mathrm{c}}$ Robert L. Copeland, ${ }^{\mathrm{d}}$ Samuel R Denmeade, ${ }^{\mathrm{e}}$ Oladapo Bakare, ${ }^{\mathrm{a}}$

${ }^{a}$ Department of Chemistry, Howard University, 525 College St NW, Washington DC, 20059, USA

${ }^{\mathrm{b}}$ Cancer Center, Howard University, Washington DC, 20059, USA

${ }^{\mathrm{c} C u r r e n t l y ~ a t ~ A r c h e r ~ D a n i e l ~ M i d l a n d ~ C o m p a n y, ~ J a m e s ~ R ~ R a n d a l l ~ R e s e a r c h ~ C e n t e r, ~}$ Decatur, IL 62521, USA

${ }^{\mathrm{d}}$ Department of Pharmacology, College of Medicine, Howard University, Adams Bldg., $520 \mathrm{~W}$ St NW, Washington, DC, 20059, USA

${ }^{\mathrm{e}}$ The Sidney Kimmel Comprehensive Cancer Center at Johns Hopkins, The Johns Hopkins School of Medicine, 1650 Orleans St, Baltimore, MD 21231, USA

Keywords: Emetine; Dithiocarbamate ester; Anti-cancer activities; Prostate cancer; Emetine derivatives

* Corresponding author: O. Bakare Tel: 202-806-6888; Fax: 202-806-5442; E-mail: obakare@howard.edu 


\begin{abstract}
A small library of emetine dithiocarbamate ester derivatives were synthesized in $25-86 \%$ yield via derivatization of the $\mathrm{N} 2{ }^{\prime}$ - position of emetine. Anticancer evaluation of these compounds in androgen receptor positive $\mathrm{LNCaP}$ and androgen receptor negative PC3 and DU145 prostate cancer cell lines revealed time dependent and dose-dependent cytotoxicity. With the exception of compound 4c, all the dithiocarbamate ester analogs in this study showed appreciable potency in all the prostate cancer cell lines (regardless of whether it is androgen receptor positive or negative) with a cytotoxicity $\mathrm{IC}_{50}$ value ranging from $1.312 \pm 0.032 \mu \mathrm{M}$ to $5.201 \pm 0.125 \mu \mathrm{M}$ by day 7 of treatment. Compared to the sodium dithiocarbamate salt $\mathbf{1}$, all the dithiocarbamate ester analogs $(\mathbf{2}$ and $\mathbf{4 a - 4 g})$ displayed lower cytotoxicity than compound $\mathbf{1}\left(\mathrm{PC} 3, \mathrm{IC}_{50}=0.087 \pm 0.005\right.$ $\mu \mathrm{M}$; DU145, $\mathrm{IC}_{50}=0.079 \pm 0.003 \mu \mathrm{M}$ and $\left.\mathrm{LNCaP}, \mathrm{IC}_{50}=0.079 \pm 0.003 \mu \mathrm{M}\right)$ on day 7 of treatment. Consequently, it appears that S-alkylation of compound $\mathbf{1}$ leads to a more stable dithiocarbamate ester derivative that resulted in lower anticancer activity in the prostate cancer cell lines.
\end{abstract}




\section{Introduction}

Prostate cancer is the most common non-cutaneous malignancy among American men. Patients diagnosed at stage III and IV of the disease, are usually treated with androgen-deprivation therapy (surgical or chemical castration) and virtually all patients progress to the castration resistant stage and ultimately resulting in mortality once it escapes the confines of the gland. It was estimated that more than 29,000 men in the United States would die from prostate cancer in 2014. ${ }^{1}$ Recently, several new agents have been approved for the treatment of castration resistant disease based on a few months median survival improvement over placebo. These include antiandrogen therapy abiraterone acetate and enzalutamide, second-line chemotherapy with cabazitaxel, bone-targeted denosumab, radiation therapy with radium-223 and immunotherapy vaccine, sipuleucel-T. ${ }^{2,3}$ All these agents only extend patient life by several months and there remains an urgent need to develop new therapies for castration resistant prostate cancer. ${ }^{3}$ Currently, efforts are being directed along several frontlines to develop more efficacious therapy with unique anticancer mechanisms, improved survival benefit and relatively low systemic toxicity to normal cells. ${ }^{3,4}$ Natural products continue to be valuable source of compounds with tremendous biological and medicinal importance including compounds with excellent anticancer activities. Thus, natural products remain a vital source of scaffolds and compounds for the development of useful anticancer agents. In our efforts to develop clinically useful anticancer agents based on natural products scaffold, we find emetine to be an attractive scaffold for chemical transformation. 

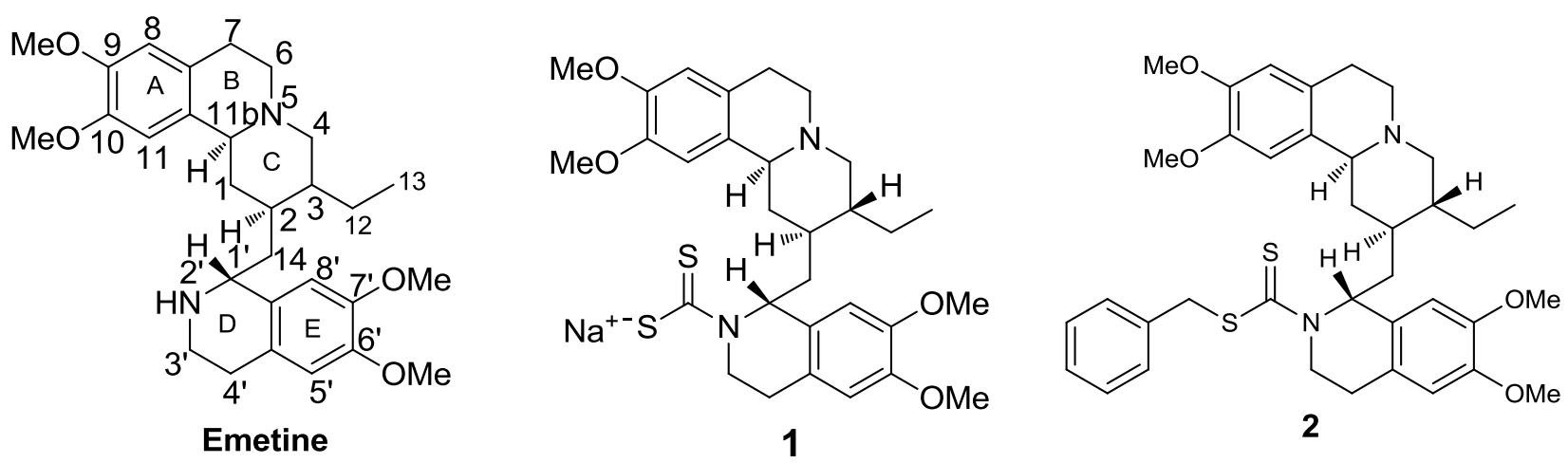

Akinboye and Bakare recently reviewed the biological activities of emetine; this account shows the versatility of emetine as a bio-active natural product. ${ }^{5}$ Among other biological activities, it is a well known anti-cancer alkaloid from Psychotria ipecacuanha. ${ }^{6-8}$ Its anticancer activity was evaluated in several clinical studies up to Phase II for treating solid tumor, however narrow therapeutic index and dose dependent side effects stopped further studies. ${ }^{9}$ Recently, some studies reported novel mechanisms of action for the cytotoxicity of emetine. For instance, among other alkaloids screened for the inhibition of the activation of Hypoxia-inducible Factor-1 (HIF1) in breast cancer, emetine demonstrated an appreciable potency. ${ }^{6}$ It regulates the alternative splicing of Bcl-x Pre-mRNA, producing an up-regulation of the levels of the pro-apoptotic variant, $\mathrm{Bcl}-\mathrm{xS}$, and down-regulation of the levels of the anti-apoptotic variant $\mathrm{Bcl}-\mathrm{xL}$ in different cancer cell lines. ${ }^{10}$ In a separate study on leukemia cells, emetine itself induced apoptosis, and also improved drug-induced apoptosis when combined with other chemotherapeutic agents. ${ }^{11}$ Smukste and co-workers, in a study on the use of small molecules to overcome drug resistance induced by a viral oncogene, also reported emetine and other protein synthesis inhibitors to potentiate the lethality of doxorubicin in RKO-E6 cell. ${ }^{12}$ More interestingly, emetine has been found to be a substrate of permeability glycoprotein (P-gp) ${ }^{13}$ The glycoprotein (P-gp) is a membrane protein that pumps drug molecules out of cells so that they cannot elicit their cytotoxic effects, therefore, contributing significantly to multidrug resistance 
(MDR). Consequently, a small library of emetine homodimers was designed and synthesized to probe the substrate binding sites of P-gp. ${ }^{14}$ One of these homodimers was reported to reverse the MDR phenotype of MCF-7/DX1 cells at a non-cytotoxic concentration when co-administered with cytotoxic agent such as doxorubicin. ${ }^{14}$ Thus, it appears that modification of emetine could lead to anticancer drug candidates with better therapeutic index.

In our approach to obtain emetine derivatives without acute systemic toxicity, but still retaining anti-cancer potency, we designed the derivatization of the $\mathrm{N}^{2}$ - position of emetine into biologically interesting compounds for bioactivity studies. We initially synthesized and evaluated the anti-prostate cancer activities of a diverse library of hydrolysable analogs and prodrugs of emetine involving a variety of functional moieties. Among the compounds studied in a 7 day drug treatment, the emetine dithiocarbamate salt $\mathbf{1}$ showed considerable potency in the prostate cancer cell lines studied $\left(\mathrm{PC} 3, \mathrm{IC}_{50}=0.087 \pm 0.005 \mu \mathrm{M} ; \mathrm{LNCaP}, \mathrm{IC}_{50}=0.079 \pm 0.003\right.$ $\mu \mathrm{M})$ compared to the rest of the analogs studied. Upon alkylation of $\mathbf{1}$ to form the benzyl dithiocarbamate ester 2 , the cytotoxic activity was reduced $\left(\mathrm{PC} 3, \mathrm{IC}_{50}=1.560 \mu \mathrm{M} ; \mathrm{LNCaP}, \mathrm{IC}_{50}\right.$ $=1.970 \mu \mathrm{M}) \cdot{ }^{15}$ In order to establish the effect of alkylation of $\mathbf{1}$ on the anticancer properties of the resulting dithiocarbamate ester and establish structure activity relationship (SAR) studies that would allow us to identify a lead emetine dithiocarbamate ester derivative for further studies, we designed the synthesis and anticancer studies of a small library of emetine dithiocarbamate ester derivatives. In addition, incorporating the dithiocarbamate moiety into a library of emetine analogs is of interest to us because the presence of this moiety in a number of compounds has been associated with anti-carcinogenic, anti-mutagenic, and cancer chemo-preventive activities. ${ }^{16-19}$ In the present paper, we have carried out a time-dependent cytotoxicity study of compound 2 and seven other dithiocarbamate ester analogs in androgen receptor positive LNCaP 
and androgen receptor negative PC3 and DU145 prostate cancer cell lines. We herein report the synthesis, characterization and preliminary anti-prostate cancer activities of a small library of emetine dithiocarbamate ester analogs.

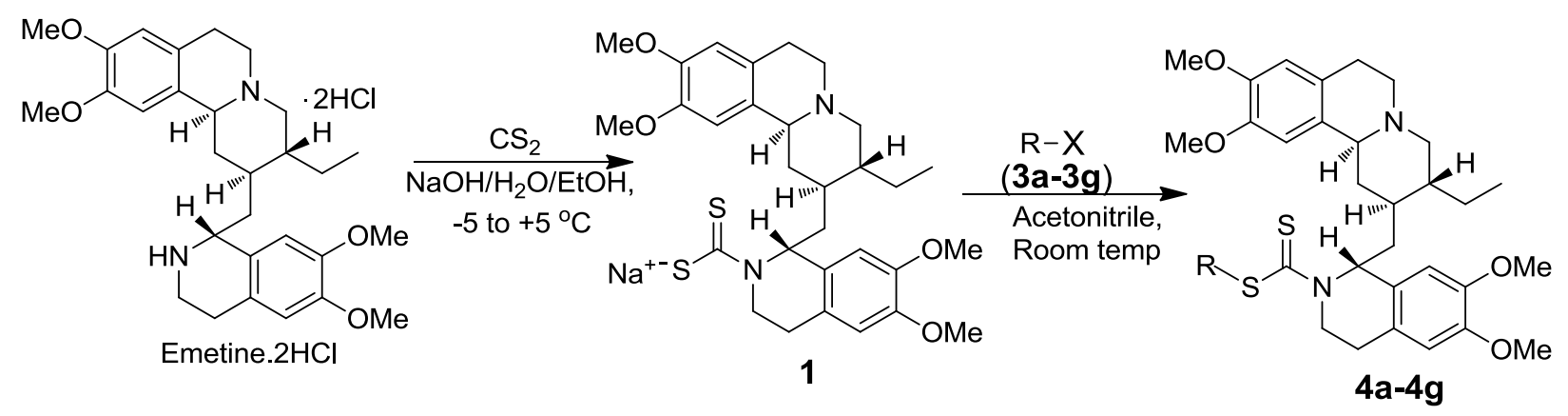

Scheme 1. General synthetic scheme for the synthesis of dithiocarbamate ester analogs of emetine. R-X represents the various alkylating agents employed in the $\mathrm{S}_{\mathrm{N}} 2$ reactions<smiles>CCCCCCBr</smiles>

$3 a$<smiles>O=C(CCl)Nc1ccc(Br)cc1</smiles>

$3 d$<smiles>COC(=O)CCCCBr</smiles>

$3 \mathbf{b}$<smiles>NC(=O)CCCl</smiles>

3c<smiles>O=C(CCl)c1ccc(Cl)cc1</smiles>

$3 e$<smiles>CCOC(=O)c1ccc(NC(=O)CCl)cc1</smiles><smiles>O=C1c2ccccc2C(=O)N1CCBr</smiles>

$3 g$

Fig. 1 Set of alkylating agents (R-X) for the synthesis 


\section{Results and Discussion}

\subsection{Chemistry}

As we previously ${ }^{15}$ described for compound 2, the synthesis of the dithiocarbamate analogs of emetine $(\mathbf{4 a}-\mathbf{4 g})$ commenced with the conversion of emetine dihydrochloride salt to the dithiocarbamate salt 1 by treating a solution of emetine dihydrochloride salt in ethanolic $\mathrm{NaOH}$ with carbon disulfide (Scheme 1). Compound 1 was obtained in almost quantitative yield. Subsequent reaction of $\mathbf{1}$ with different alkylating agents $\mathbf{3 a - 3 g}$ (figure 1) in acetonitrile furnished the dithiocarbamate ester analogs of emetine (4a-4g) in 25 to $86 \%$ yield. The resulting crude product was subjected to a short flash chromatography on silica gel column using different ratios of methanol and ethyl acetate as eluent. The main impurity is believed to result from decomposition of the dithiocarbamate salt, which resulted in a more polar byproduct than the dithiocarbamate ester analog as shown by thin-layer chromatography (TLC) on silica. No attempt was made to further isolate and characterize this by-product. All compounds were characterized by infrared, ${ }^{1} \mathrm{H}$ and ${ }^{13} \mathrm{C}-\mathrm{nmr}$ spectroscopy as well as by electrospray ionization mass spectrometry. 


\subsection{Biology}

In a seven-day exposure, we initially compared the cytotoxicity of emetine, the dithiocarbamate salt $\mathbf{1}$ and a benzyl substituted dithiocarbamate ester analog 2 of emetine in PC3 and LNCaP. ${ }^{15}$ In this study, emetine was about three folds more potent than the dithiocarbamate salt $\mathbf{1}$ while it was about 50 folds more potent than the dithiocarbamate ester analog in PC3. We established in this initial study that the dithiocarbamate salt $\mathbf{1}$ served as a prodrug of emetine and was hydrolyzed to emetine in the slightly acidic cancer cell growth medium mimicking the cancerous tumor microenvironment, whereas the dithiocarbamate ester $\mathbf{2}$ was more stable as a result of S-alkylation of the dithiocarbamyl group. More importantly, a preliminary evaluation of the safety of compound $\mathbf{1}$ in healthy mice compared to emetine suggested that the dithiocarbamate salt $\mathbf{1}$ is safer than emetine in vivo. Specifically, mice that received a single dose of emetine at $100 \mathrm{mg} / \mathrm{kg}$ body weight all died within 48 hours. On the other hand, $100 \mathrm{mg} / \mathrm{kg}$ body weight of compound 1 did not produce observable lethality. Further, when $33 \mathrm{mg} / \mathrm{kg}$ body weight of emetine or compound $\mathbf{1}$ was administered, mice that received emetine were lethargic and showed about four times weight loss compared with control; while, mice that received compound $\mathbf{1}$ appeared healthy and did not show any significant difference in

weight compared with control. ${ }^{15}$ These results encouraged us to pursue further anticancer evaluation of derivatives of compound $\mathbf{1}$ similar to compound $\mathbf{2}$. We were interested in developing more stable analogs that would not necessarily act as prodrugs, but would retain anticancer activities while minimizing the toxicities associated with emetine. Such a compound would be closely related to compound $\mathbf{1}$ that we have proven to be safer than emetine in vivo. The availability of such compounds from emetine would make available clinically useful compounds that could be used in combination therapy with existing anticancer drugs, if not as a stand-alone chemotherapeutic agent. This will be beneficial for the treatment of metastatic castration-resistant prostate cancer particularly when the cancer is not responding to available treatment options as a result of drug resistance to currently used chemotherapeutic agents. 
Consequently, we set out to design a small library of dithiocarbamate ester analogs of emetine with potential anticancer properties and investigate the effects of various types of "alkyl groups" on the potency of the dithiocarbamate ester analogs of emetine in the androgen receptor positive LNCaP and negative PC3 and DU145 prostate cancer cell lines. Each alkylating agent we employed is unique, but they all can be grouped into two categories: "aliphatic (non-aromatic)" which gave compounds $\mathbf{4 a - 4 c}$ and "aromatic" which gave $\mathbf{4 d - 4 g}$. Our goal is to incorporate diversity into this small chemical library to investigate the effects of the structure and functional groups of each group on the general anticancer activity of the analogs and possibly identify a lead dithiocarbamate ester derivative. The cytotoxicity assay was done with a maximum drug concentration of $10 \mu \mathrm{M}$; any drug with cytotoxicity $\mathrm{IC}_{50}$ value greater than $10 \mu \mathrm{M}$ is categorized as inactive and such values are not reported (Tables 1 to 3 and figures 2A-C).

Looking at the effects of analogs $\mathbf{2}$ and $\mathbf{4 a}-\mathbf{4 g}$, it was observed that by day 3 all the compounds, except $\mathbf{4 c}$, showed appreciable potency in all the prostate cancer cell lines (regardless of whether it is androgen receptor positive or negative) with a cytotoxicity $\mathrm{IC}_{50}$ value less than $10 \mu \mathrm{M}$ (Table 1). Compounds $4 \mathbf{a}, \mathbf{4 b}$ and $\mathbf{4 c}$ are designed with aliphatic (non-aromatic) alkyl group, and different functionalities at the aliphatic chain terminal. Compound $\mathbf{4 c}$ has an amide functional group terminal and has a shorter chain (about three carbon shorter) than $\mathbf{4 a}$ and $\mathbf{4 b}$. As such, its relatively low potency within the first 3 days of exposure as seen in all the three cell lines, could be due to a number of factors including chain length, possible H-bonding from the terminal amide or may be due to poor cellular uptake. In both $\mathrm{LNCaP}$ and PC3, its potency increased as the exposure period increased to five days $\left(\mathrm{LNCaP}, \mathrm{IC}_{50}=4.732 \mu \mathrm{M} ; \mathrm{PC} 3, \mathrm{IC}_{50}=6.562 \mu \mathrm{M}\right)$ and seven days $\left(\mathrm{LNCaP}, \mathrm{IC}_{50}=3.390 \mu \mathrm{M} ; \mathrm{PC} 3, \mathrm{IC}_{50}=5.201 \mu \mathrm{M}\right)$ as shown in fig 2. Though 
generally more potent than $\mathbf{4 c}$, compound $\mathbf{4 b}$, with an ester functional group at the terminal of the aliphatic chain, is relatively less potent in the more aggressive PC3 than the other two cell lines (Tables 1, 2, 3). On the contrary, 4a without any other functionality on the hexyl chain shows consistent potency across the three cell lines with appreciable anticancer activity observed within the first three days $\left(\mathrm{LNCaP}, \mathrm{IC}_{50}=3.659 \mu \mathrm{M}\right.$; PC3, $\mathrm{IC}_{50}=5.978 \mu \mathrm{M}$; DU145, $\mathrm{IC}_{50}=$ $3.658 \mu \mathrm{M})$. Compound 4a appears to be the most potent of the three alkyl-substituted analogs showing time-dependent increase in cytotoxicity in all three cell lines by day $5\left(\mathrm{LNCaP}, \mathrm{IC}_{50}=\right.$ $\left.1.613 \mu \mathrm{M} ; \mathrm{PC} 3, \mathrm{IC}_{50}=3.21 \mu \mathrm{M} ; \mathrm{DU} 145, \mathrm{IC}_{50}=3.189 \mu \mathrm{M}\right)$, and day $7\left(\mathrm{LNCaP}, \mathrm{IC}_{50}=1.592\right.$ $\mu \mathrm{M} ; \mathrm{PC} 3, \mathrm{IC}_{50}=3.027 \mu \mathrm{M} ; \mathrm{DU} 145, \mathrm{IC}_{50}=2.300 \mu \mathrm{M}$ ) [Tables 1, 2, 3 and Figs. 2A-C].

Compounds $\mathbf{2}, \mathbf{4 d}, \mathbf{4 e}, \mathbf{4 f}$, and $\mathbf{4 g}$ have aromatic group in the dithiocarbamate ester substituent. Unlike compounds $\mathbf{4 a}, \mathbf{4 b}$, and $\mathbf{4} \mathbf{c}$, each compound in this category shows almost the same level of potency across the three cell lines with compounds $2\left(\mathrm{LNCaP}, \mathrm{IC}_{50}=1.312 \mu \mathrm{M} ; \mathrm{PC} 3, \mathrm{IC}_{50}=\right.$ $\left.1.560 \mu \mathrm{M} ; \mathrm{DU} 145, \mathrm{IC}_{50}=1.980 \mu \mathrm{M}\right)$ and $4 \mathbf{d}\left(\mathrm{LNCaP}, \mathrm{IC}_{50}=1.698 \mu \mathrm{M} ; \mathrm{PC} 3, \mathrm{IC}_{50}=1.507 \mu \mathrm{M}\right.$; DU145, $\mathrm{IC}_{50}=1.603 \mu \mathrm{M}$ ) showing the lowest $\mathrm{IC}_{50}$ values (less than $2 \mu \mathrm{M}$ ) in all three cell lines by day 7 [Tables 1, 2, 3 and Figs. 2A-C]. Further, all the analogs $\mathbf{2}$ and $\mathbf{4 d}-\mathbf{4 g}$ show a gradual increase in potency between day 3 and day 7 of exposing the prostate cancer cell lines to the analogs (Tables 1 to 3 ). The resulting dithiocarbamate esters in this study $(\mathbf{2}, \mathbf{4 a}-\mathbf{4 g})$ do not necessarily act as prodrugs, but rather as less toxic analogs of emetine. The slight differences in cytotoxicity observed in this study is most likely due to conformational differences resulting from the size and nature of each substituent group. As previously reported, replacement of the secondary amine hydrogen of the N-2 position of emetine with a bulkier group would eliminate an electronic effect as a result of loss of possible $\mathrm{H}$-bonding of the $\mathrm{N}-\mathrm{H}$ with potential receptors at the active site. In addition, any substituted group would result in conformational changes 
which appear to affect the space between the tricyclic and bicyclic ring system of emetine and consequently affect the bioactivity of the resulting analog including protein synthesis inhibitory and anticancer activities. ${ }^{5,15,20}$ Hence, an appropriate substituent in this position would result in a clinically useful emetine prodrug, or an emetine derivative that does not have the same systemic toxicity as emetine. We are currently studying a diverse library of emetine analogs in this regard.

In summary, all the analogs $\mathbf{2}$ and $\mathbf{4 a - 4 g}$ consistently displayed lower cytotoxicity than compound $\mathbf{1}$, establishing the fact that once compound $\mathbf{1}$ is stabilized by S-alkylation, the cytotoxic effect of the resulting dithiocarbamate ester $(\mathbf{2}, \mathbf{4 a}-\mathbf{4 g})$ is decreased relative to $\mathbf{1}$. In addition, for all the compounds $(\mathbf{2}, \mathbf{4 a}-\mathbf{4 g})$ there was a time dependent increase in cytotoxicity between day 3 and day 7 of the study in androgenreceptor positive $\mathrm{LNCaP}$ and androgen receptor negative PC3. The only exception is seen in the androgenreceptor negative DU145 where compound $\mathbf{4 c}$ consistently showed $\mathrm{IC}_{50}$ value of over $10 \mu \mathrm{M}$ between days 3 to 7 . The reason for this exception is not immediately apparent as the same compound $\mathbf{4 c}$ showed some increase in potency ( $\mathrm{IC}_{50}$ of less than $10 \mu \mathrm{M}$ by day 5 and 7 ) in the more aggressive androgen receptor negative PC3 prostate cancer cell line (Tables 1 to 3 and figures $2 \mathrm{~A}-\mathrm{C}$ ). Also, it is important to note that nearly all the compounds showed appreciable potency in all the prostate cancer cell lines regardless of whether it is androgen receptor positive or androgen receptor negative. This might suggest a mechanism of action that is independent of the androgen receptor. Finally, of the eight compounds studied here, compounds $\mathbf{2}$ and $\mathbf{4 d}$ appear to be the most consistently potent in all three cell lines and further SAR around these two compounds could lead to more active analogs that could be clinically useful in combination therapy with existing anticancer drugs, if not as a stand-alone chemotherapeutic agent in the treatment of metastatic castration-resistant prostate cancer. 


\section{Acknowledgment}

We gratefully acknowledge grant number 5-U54-CA914-31 (Howard University/Johns Hopkins

Cancer Center Partnership) and MRI grant number CHE-1126533 from the National Science Foundation.

Table 1 Cytotoxicity of dithiocarbamate analogs of emetine in androgen receptor positive (LNCaP) and negative (PC3 and DU145) on day 3 of exposure

\begin{tabular}{|l|l|l|l|}
\hline \multicolumn{3}{|c|}{ Cytotoxicity IC $50(\boldsymbol{\mu M})$ on day 3 } \\
\hline Compound & LNCaP & DU145 \\
\hline $\mathbf{1}$ & $0.565 \pm 0.012$ & $0.442 \pm 0.036$ & $0.377 \pm 0.018$ \\
\hline $\mathbf{2}$ & $1.966 \pm 0.088$ & $2.535 \pm 0.099$ & $2.741 \pm 0.092$ \\
\hline 4a & $3.659 \pm 0.044$ & $5.978 \pm 0.168$ & $3.658 \pm 0.053$ \\
\hline 4b & $4.785 \pm 0.137$ & $8.264 \pm 0.006$ & $3.220 \pm 0.031$ \\
\hline 4c & $9.217 \pm 0.709$ & $>10.000$ & $>10.000$ \\
\hline 4d & $5.280 \pm 0.191$ & $3.868 \pm 0.277$ & $5.654 \pm 0.319$ \\
\hline 4e & $5.721 \pm 0.092$ & $3.594 \pm 0.113$ & $3.170 \pm 0.158$ \\
\hline 4f & $4.667 \pm 0.132$ & $4.363 \pm 0.084$ & $5.157 \pm 0.101$ \\
\hline 4g & $3.221 \pm 0.117$ & $3.207 \pm 0.071$ & $3.809 \pm 0.051$ \\
\hline Emetine & $0.037 \pm 0.001$ & $0.035 \pm 0.001$ & $0.033 \pm 0.001$ \\
\hline
\end{tabular}


Table 2 Cytotoxicity of dithiocarbamate analogs of emetine in androgen receptor positive (LNCaP) and negative (PC3 and DU145) on day 5 of exposure

\begin{tabular}{|l|l|l|l|}
\hline \multicolumn{3}{|c|}{ Cytotoxicity IC $50(\mu M)$ on day 5 } \\
\hline Compound & LNCaP & DU145 \\
\hline $\mathbf{1}$ & $0.088 \pm 0.003$ & $0.091 \pm 0.006$ & $0.080 \pm 0.001$ \\
\hline $\mathbf{2}$ & $1.890 \pm 0.092$ & $2.021 \pm 0.049$ & $2.070 \pm 0.103$ \\
\hline 4a & $1.613 \pm 0.066$ & $3.21 \pm 0.117$ & $3.189 \pm 0.078$ \\
\hline 4b & $2.308 \pm 0.174$ & $4.855 \pm 0.153$ & $3.148 \pm 0.007$ \\
\hline 4c & $4.732 \pm 0.352$ & $6.562 \pm 0.913$ & $>10.000$ \\
\hline 4d & $2.189 \pm 0.075$ & $2.768 \pm 0.146$ & $2.796 \pm 0.151$ \\
\hline 4e & $2.312 \pm 0.023$ & $2.700 \pm 0.133$ & $3.197 \pm 0.193$ \\
\hline 4f & $2.717 \pm 0.135$ & $2.706 \pm 0.192$ & $2.898 \pm 0.137$ \\
\hline 4g & $2.801 \pm 0.099$ & $2.770 \pm 0.060$ & $3.575 \pm 0.418$ \\
\hline Emetine & $0.027 \pm 0.003$ & $0.027 \pm 0.002$ & $0.025 \pm 0.001$ \\
\hline & & & \\
\hline & & & \\
\hline
\end{tabular}


Table 3 Cytotoxicity of dithiocarbamate analogs of emetine in androgen receptor positive (LNCaP) and negative (PC3 and DU145) on day 7 of exposure

\begin{tabular}{|l|l|l|l|}
\hline \multicolumn{3}{|c|}{ Cytotoxicity IC } & \\
\hline Compound & LNCaP on day 7 & PC3 & DU145 \\
\hline $\mathbf{1}$ & $0.079 \pm 0.003$ & $0.087 \pm 0.003$ & $0.079 \pm 0.003$ \\
\hline $\mathbf{2}$ & $1.312 \pm 0.032$ & $1.560 \pm 0.290$ & $1.980 \pm 0.213$ \\
\hline $\mathbf{4 a}$ & $1.592 \pm 0.014$ & $3.027 \pm 0.160$ & $2.300 \pm 0.067$ \\
\hline $\mathbf{4 b}$ & $1.763 \pm 0.039$ & $4.355 \pm 0.091$ & $2.253 \pm 0.084$ \\
\hline $\mathbf{4 c}$ & $3.390 \pm 0.339$ & $5.201 \pm 0.125$ & $>10.000$ \\
\hline $\mathbf{4 d}$ & $1.698 \pm 0.187$ & $1.507 \pm 0.896$ & $1.603 \pm 0.093$ \\
\hline $\mathbf{4 e}$ & $1.951 \pm 0.068$ & $2.692 \pm 0.145$ & $2.449 \pm 0.162$ \\
\hline $\mathbf{4 f}$ & $1.656 \pm 0.564$ & $1.902 \pm 0.134$ & $2.467 \pm 0.263$ \\
\hline $\mathbf{4 g}$ & $2.303 \pm 0.121$ & $2.378 \pm 0.240$ & $3.050 \pm 0.070$ \\
\hline Emetine & $0.037 \pm 0.001$ & $0.029 \pm 0.003$ & $0.024 \pm 0.001$ \\
\hline
\end{tabular}


A

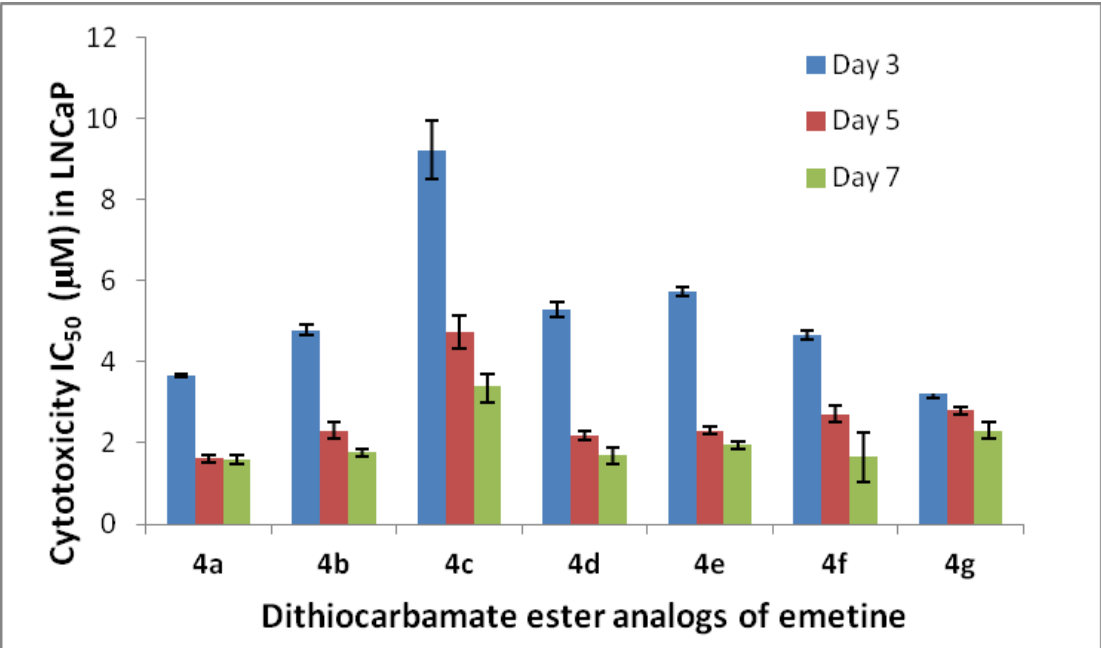

B

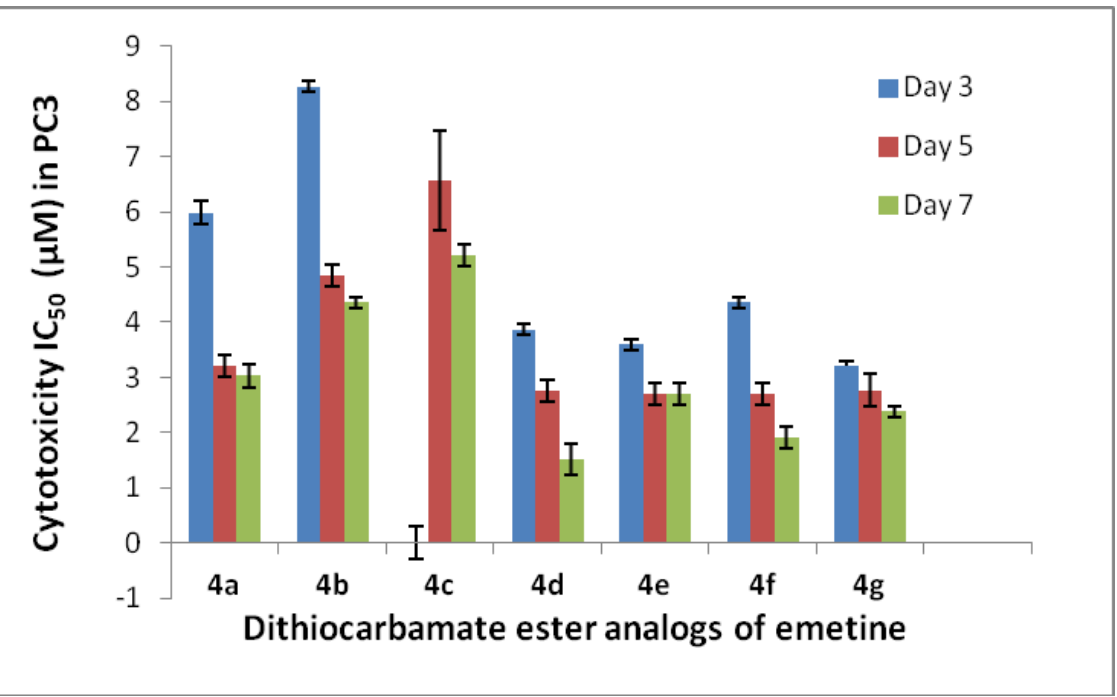


C

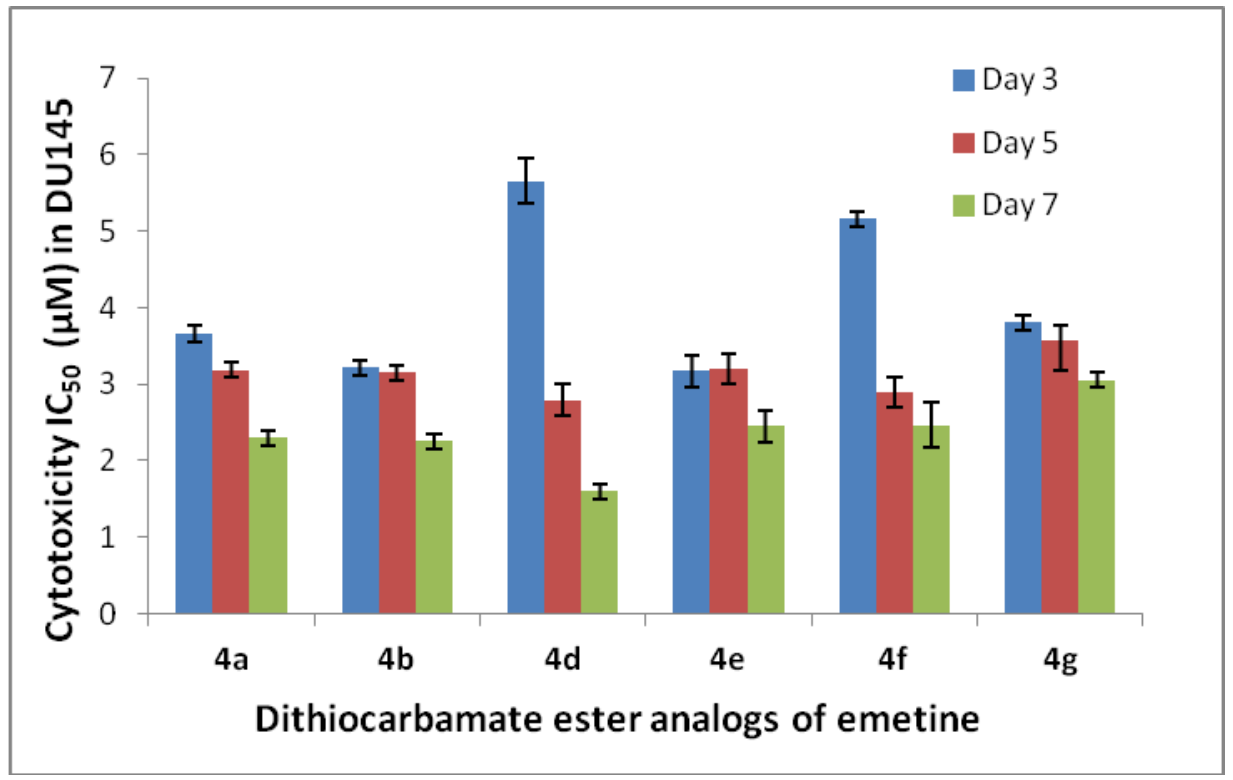

Figure 2. Variation of the cytotoxicity $\mathrm{IC}_{50}$ of the dithiocarbamate analogs of emetine with time over the seven-day exposure. A. Cytotoxicity $\mathrm{IC}_{50}$ values in $\mathrm{LNCaP}$ on the $3^{\text {rd }}, 5^{\text {th }}$ and $7^{\text {th }}$ day of exposure. B. Cytotoxicity $\mathrm{IC}_{50}$ values in $\mathrm{PC} 3$ on the $3^{\text {rd }}, 5^{\text {th }}$ and $7^{\text {th }}$ day of exposure.

C. Cytotoxicity $\mathrm{IC}_{50}$ values in DU145 on the $3^{\text {rd }}, 5^{\text {th }}$ and $7^{\text {th }}$ day of exposure 


\section{Experimental Section}

\subsection{Chemistry: general procedures}

All solvents and reagents used were bought from commercial sources and used without any further purification. Melting points were determined in open capillary tubes on a Mel-Temp melting point apparatus and are uncorrected. The ${ }^{1} \mathrm{H}$ - and ${ }^{13} \mathrm{C}-\mathrm{NMR}$ spectra were obtained on a Bruker Avance $400 \mathrm{MHz}$ spectrometer in deuterated chloroform $\left(\mathrm{CDCl}_{3}\right)$ or deuterated methanol $\left(\mathrm{CD}_{3} \mathrm{OD}\right)$. Chemical shifts are in $\delta$ units $(\mathrm{ppm})$ with TMS $(0.00 \mathrm{ppm}), \mathrm{CHCl}_{3}(7.27 \mathrm{ppm})$, or $\mathrm{CH}_{3} \mathrm{OH}(3.34 \mathrm{ppm})$ as the internal standard for ${ }^{1} \mathrm{H}-\mathrm{NMR}$, and $\mathrm{CDCl}_{3}(77.00 \mathrm{ppm})$ or $\mathrm{CD}_{3} \mathrm{OD}$ (49.90 ppm) for ${ }^{13} \mathrm{C}-\mathrm{NMR}$. The samples were analyzed with a Waters quadrupole Time-ofFlight (QTOF) mass spectrometer (micro model) equipped with both Electrospray Ionization (ESI) and Atmospheric Pressure Chemical Ionization (APCI). The instrument was operated in positive-ion $\left(\mathrm{ESI}^{+}\right)$single-stage mode. The MS was calibrated in the mass-to-charge $(\mathrm{m} / \mathrm{z})$ range $=100-1500$ using a solution of $2 \mu \mathrm{g} / \mathrm{mL} \mathrm{NaI}$ and $0.05 \mu \mathrm{g} / \mathrm{mL}$ CsI in isopropyl alcohol: $\mathrm{H}_{2} \mathrm{O} 1: 1$ (vol:vol) introduced into the instrument by direct infusion at a flow of $25 \mu \mathrm{L} / \mathrm{min}$. All the mass spectra showed signals corresponding to the molecular ion plus sodium $(\mathrm{Na})$. The sodium was picked up from the conditions used to operate the instrument, as is common in this type of mass spectrometry, and was not present in the actual compounds themselves.

\subsection{Synthesis of sodium salt of dithiocarbamic acid of emetine 1.}

Sodium 1-(3-Ethyl-9,10-dimethoxy-1,3,4,6,7,11b-hexahydro-2H-pyrido[2,1-a]isoquinolin-2ylmethyl)-6,7-dimethoxy-3,4-dihydro-1H-isoquinoline-2-carbodithioate (1). A solution of $\mathrm{NaOH}(240.0 \mathrm{mg})$ in water $(1.00 \mathrm{ml})$ and ethanol $(20.00 \mathrm{ml})$ was added to a solution of emetine dihydrochloride hydrate $(1.11 \mathrm{~g}, 2.00 \mathrm{mmol})$ in ethanol $(10.0 \mathrm{ml})$ at $-8^{\circ} \mathrm{C}$. This was stirred at this 
temperature for $15 \mathrm{~min}$ after which $\mathrm{CS}_{2}(0.30 \mathrm{~mL}, 4.97 \mathrm{mmol})$ was added. The resulting mixture was stirred at -5 to $1^{\circ} \mathrm{C}$ for $2 \mathrm{~h}$ and at room temperature for $30 \mathrm{~min}$. The solvent was removed invacuo and the residue triturated with acetonitrile and then filtered. The filtrate was evaporated to dryness and the residue dissolved in ethyl acetate $(3 \mathrm{~mL})$. To this was added diethyl ether which afforded the precipitation of $\mathbf{1}$ as a white solid $(950.0 \mathrm{mg}, 82.0 \%) .{ }^{1} \mathrm{H}$ NMR (400 MHz, $\mathrm{CD}_{3} \mathrm{OD}$ ) $\delta 0.93(3 \mathrm{H}, \mathrm{t}, \mathrm{J}=7.4 \mathrm{~Hz}), 1.10-1.23(1 \mathrm{H}, \mathrm{m}), 1.14-1.20(2 \mathrm{H}, \mathrm{m}), 1.33-1.41(2 \mathrm{H}, \mathrm{m}), 1.66-1.72$ $(1 \mathrm{H}, \mathrm{m}), 2.10(1 \mathrm{H}, \mathrm{t}, \mathrm{J}=11.0 \mathrm{~Hz}), 2.38(1 \mathrm{H}, \mathrm{t}, \mathrm{J}=12.8 \mathrm{~Hz}), 2.50(1 \mathrm{H}, \mathrm{tb}, \mathrm{J}=4.1,11.6 \mathrm{~Hz})$, 2.63-2.70 (2H, m), 2.99-3.20 (5H, m), $3.35(1 \mathrm{H}, \mathrm{s}), 3.44-3.51(1 \mathrm{H}, \mathrm{m}) 3.80(3 \mathrm{H}, \mathrm{s}), 3.81(6 \mathrm{H}, \mathrm{br}$ s), $3.84(3 \mathrm{H}, \mathrm{s}), 5.95(1 \mathrm{H}, \mathrm{dd}, \mathrm{J}=5.9,12.8 \mathrm{~Hz}), 6.66(1 \mathrm{H}, \mathrm{s}), 6.69(1 \mathrm{H}, \mathrm{s}), 6.72(1 \mathrm{H}, \mathrm{s}), 7.20$ $(1 \mathrm{H}, \mathrm{s}), 7.25(1 \mathrm{H}, \mathrm{dd}, \mathrm{J}=3.6,11.8 \mathrm{~Hz}) .{ }^{13} \mathrm{C} \mathrm{NMR}\left(100 \mathrm{MHz}, \mathrm{CD}_{3} \mathrm{OD}\right) \delta 216.5,147.4,147.3$, $147.2,147.1,133.0,131.1,127.0,126.5,112.6,112.0,111.0,110.3,65.4,63.3,61.6,58.0,56.5$, $56.2,56.1,56.0,55.9,52.5,41.7,41.3,37.6,29.4,27.3,23.7,11.6$.

\subsection{General procedure for the synthesis of the dithiocarbamate ester derivatives of} emetine. For the synthesis of each of compounds $\mathbf{4 a - 4 g}$, the salt $\mathbf{1}$ (200 $\mathrm{mg}, 0.35 \mathrm{mmol}$ ) was dissolved in acetonitrile $(15 \mathrm{~mL})$ and to this was added a solution of alkylating agents $\mathbf{3 a - 3 g}$ (0.27 mmol.) in acetonitrile. The reaction mixtures were allowed to stir for $24 \mathrm{~h}$ at room temperature. Solvent was evaporated in-vacuo. Residue obtained was triturated with water (20 $\mathrm{mL}$ ) to dissolve any inorganic substances, and then filtered under suction. The crude product was air-dried and then purified by flash chromatography on silica gel using EtOAc: $\mathrm{MeOH}(10: 1)$ as eluent. 
3.3.1. 1-(3-Ethyl-9,10-dimethoxy-1,3,4,6,7,11b-hexahydro- $2 H$-pyrido[2,1-a]isoquinolin-2-ylmethyl)-6,7-dimethoxy-3,4-dihydro-1H-isoquinoline-2-carbodithioic acid hexyl ester (4a). Yield: $45.2 \%, \mathrm{mp}=78-80{ }^{\circ} \mathrm{C} \quad{ }^{1} \mathrm{H}$ NMR $\left(400 \mathrm{MHz}, \mathrm{CDCl}_{3}\right) \delta$ 0.78-0.94 $(6 \mathrm{H}, \mathrm{m}), 1.03-1.15(1 \mathrm{H}$, m), 1.16-1.32 (7H, m), 1.33-1.53 (4H, m), 1.55-1.75 (3H, m), $2.03(1 \mathrm{H}, \mathrm{ds} t, \mathrm{~J}=10.0 \mathrm{~Hz}), 2.36-$ $2.52(2 \mathrm{H}, \mathrm{m}), 2.60(1 \mathrm{H}, \mathrm{d}, \mathrm{J}=15.2 \mathrm{~Hz}), 2.77(1 \mathrm{H}, \mathrm{d}, \mathrm{J}=14.5 \mathrm{~Hz}), 2.90-2.98(1 \mathrm{H}, \mathrm{m}), 3.00-3.19$ $(3 \mathrm{H}, \mathrm{m}), 3.20-3.30(1 \mathrm{H}, \mathrm{m}), 3.31-3.39(2 \mathrm{H}, \mathrm{m}), 3.61-3.72(1 \mathrm{H}, \mathrm{m}), 3.83(3 \mathrm{H}, \mathrm{s}), 3.84(6 \mathrm{H}, \mathrm{s})$ $3.93(3 \mathrm{H}, \mathrm{s}), 4.68(1 \mathrm{H}, \mathrm{dd}, \mathrm{J}=4.8,13.9 \mathrm{~Hz}), 6.55(1 \mathrm{H}, \mathrm{s}), 6.56(1 \mathrm{H}, \mathrm{s}), 6.57(1 \mathrm{H}, \mathrm{s}), 6.86(1 \mathrm{H}$, $\mathrm{dd}, \mathrm{J}=4.1,11.5 \mathrm{~Hz}), 6.92(1 \mathrm{H}, \mathrm{s}) .{ }^{13} \mathrm{C} \mathrm{NMR}\left(100 \mathrm{MHz}, \mathrm{CDCl}_{3}\right) \delta 198.0,148.0,147.8,147.3$, $147.2,130.1,126.2,124.7,111.6,111.3,111.2,110.0,108.8,62.9,61.4,59.8,56.3,56.2,56.1$, $55.9,52.4,43.3,41.2,40.6,38.9,37.7,37.6,37.1,31.4,29.7,28.8,27.9,23.8,22.5,14.0,11.2$. HRESIMS $m / z 641.4342\left(\left[\mathrm{C}_{36} \mathrm{H}_{52} \mathrm{~N}_{2} \mathrm{O}_{4} \mathrm{~S}_{2}+\mathrm{H}\right]^{+}\right.$calcd. 641.3447).

\subsubsection{5-[1-(3-Ethyl-9,10-dimethoxy-1,3,4,6,7,11b-hexahydro-2H-pyrido[2,1-a]isoquinolin-2-} yl-methyl)-6,7-dimethoxy-3,4-dihydro-1 $H$-isoquinoline-2-carbothioylsulfanyl]-pentanoic acid methyl ester (4b). Yield: $86.2 \%, \mathrm{mp}=74-76{ }^{\circ} \mathrm{C} \quad{ }^{1} \mathrm{H}$ NMR $\left(400 \mathrm{MHz}, \mathrm{CDCl}_{3}\right) \delta 0.87$ $(3 \mathrm{H}, \mathrm{t}, \mathrm{J}=7.4 \mathrm{~Hz}), 1.01-1.15(1 \mathrm{H}, \mathrm{m}), 1.15-1.31(3 \mathrm{H}, \mathrm{m}), 1.32-1.43(1 \mathrm{H}, \mathrm{m}), 1.43-1.54(1 \mathrm{H}, \mathrm{m})$, 1.54-1.67 (1H, m),1.68-1.82(4H, m), $2.03(1 \mathrm{H}, \mathrm{t}, \mathrm{J}=7.4 \mathrm{~Hz}), 2.24-2.35(2 \mathrm{H}, \mathrm{m}), 2.36-2.53(2 \mathrm{H}$, m), $2.59(1 \mathrm{H}, \mathrm{d}, \mathrm{J}=15.6 \mathrm{~Hz}), 2.68-2.83(1 \mathrm{H}, \mathrm{m}), 2.88-2.98(1 \mathrm{H}, \mathrm{m}), 2.98-3.26(4 \mathrm{H}, \mathrm{m}), 3.27-$ $3.42(2 \mathrm{H}, \mathrm{m}), 3.62(3 \mathrm{H}, \mathrm{s}), 3.65-3.75(1 \mathrm{H}, \mathrm{m}), 3.81(3 \mathrm{H}, \mathrm{s}), 3.83(6 \mathrm{H}, \mathrm{s}), 3.92(3 \mathrm{H}, \mathrm{s}), 4.65(1 \mathrm{H}$, dd, J = 4.3, $13.6 \mathrm{~Hz}), 6.54(1 \mathrm{H}, \mathrm{s}), 6.55(1 \mathrm{H}, \mathrm{s}), 6.57(1 \mathrm{H}, \mathrm{s}), 6.82(1 \mathrm{H}, \mathrm{dd}, \mathrm{J}=3.7,11.3 \mathrm{~Hz})$, $6.70(1 \mathrm{H}, \mathrm{s}) .{ }^{13} \mathrm{C} \mathrm{NMR}\left(100 \mathrm{MHz}, \mathrm{CDCl}_{3}\right) \delta 197.1,174.2,148.5,148.3,147.8,147.7,130.5$, $130.4,128.9,126.7,125.1,111.8,110.5,109.3,63.3,62.9,60.4,56.8,56.6,56.3,52.8,46.0$ 
43.9, 41.8, 41.1, 39.4, 37.3, 36.7, 34.0, 30.2, 29.7, 28.9, 28.3, 24.7, 24.3, 11.8. HRESIMS $m / z$ $671.4057\left(\left[\mathrm{C}_{36} \mathrm{H}_{50} \mathrm{~N}_{2} \mathrm{O}_{6} \mathrm{~S}_{2}+\mathrm{H}\right]^{+}\right.$calcd. 671.3189).

\subsubsection{1-(3-Ethyl-9,10-dimethoxy-1,3,4,6,7,11b-hexahydro-2H-pyrido[2,1-a]-isoquinolin-2-} yl-methyl)-6,7-dimethoxy-3,4-dihydro-1H-isoquinoline-2-carbodithioic acid 2-carbamoyl-

ethyl ester (4c). Yield: $23.4 \%, \mathrm{mp}=107-109{ }^{\circ} \mathrm{C} \quad{ }^{1} \mathrm{H}$ NMR $\left(400 \mathrm{MHz}, \mathrm{CDCl}_{3}\right) \delta 0.88(3 \mathrm{H}, \mathrm{t}, \mathrm{J}$ $=7.4 \mathrm{~Hz}), 1.05-1.13(1 \mathrm{H}, \mathrm{m}), 1.20-1.27(3 \mathrm{H}, \mathrm{m}), 1.34-1.44(1 \mathrm{H}, \mathrm{m}), 1.45-1.57(1 \mathrm{H}, \mathrm{m}), 1.58-$ $1.69(1 \mathrm{H}, \mathrm{m}), 1.94-2.10(1 \mathrm{H}, \mathrm{m}), 2.35-2.51(2 \mathrm{H}, \mathrm{m}), 2.61(1 \mathrm{H}, \mathrm{d}, \mathrm{J}=15.9 \mathrm{~Hz}), 2.70(2 \mathrm{H}, \mathrm{t}, \mathrm{J}=$ 6.6 Hz), $2.78(1 \mathrm{H}, \mathrm{d}, \mathrm{J}=14.8 \mathrm{~Hz}), 2.86-3.27(5 \mathrm{H}, \mathrm{m}), 3.54-3.76(3 \mathrm{H}, \mathrm{m}), 3.83(3 \mathrm{H}, \mathrm{s}), 3.84(6 \mathrm{H}$, s), $3.92(3 \mathrm{H}, \mathrm{s}), 4.63(1 \mathrm{H}, \mathrm{dd}, \mathrm{J}=3.9,13.9 \mathrm{~Hz}), 5.36-5.72(2 \mathrm{H}, \mathrm{m}), 6.55(1 \mathrm{H}, \mathrm{s}), 6.56(1 \mathrm{H}, \mathrm{s})$, $6.58(1 \mathrm{H}, \mathrm{s}), 6.81(1 \mathrm{H}, \mathrm{dd}, \mathrm{J}=3.8,11.2 \mathrm{~Hz}), 6.90(1 \mathrm{H}, \mathrm{s}) .{ }^{13} \mathrm{C} \mathrm{NMR}\left(100 \mathrm{MHz}, \mathrm{CDCl}_{3}\right) \delta 197.1$, 173.2, 148.3, 147.9, 147.7, 147.3, 130.1, 129.8, 126.4, 124.6, 111.5, 111.4, 109.9, 108.9, 62.8, $61.4,59.5,56.5,56.4,56.2,56.1,56.0,52.4,41.4,40.7,40.5,38.8,37.8,35.4,29.2,27.1,23.8$, 11.2. HRESIMS $m / z 628.3776\left(\left[\mathrm{C}_{33} \mathrm{H}_{45} \mathrm{~N}_{3} \mathrm{O}_{5} \mathrm{~S}_{2}+\mathrm{H}\right]^{+}\right.$calcd. 628.2879).

\subsubsection{1-(3-Ethyl-9,10-dimethoxy-1,3,4,6,7,11b-hexahydro-2H-pyrido[2,1-a]isoquinolin-2-yl-} methyl)-6,7-dimethoxy-3,4-dihydro-1H-isoquinoline-2-carbodithioic acid (4-bromophenylcarbamoyl)-methyl ester (4d). Yield: 40.5\%, mp $=136-138{ }^{\circ} \mathrm{C} \quad{ }^{1} \mathrm{H}$ NMR $(400 \mathrm{MHz}$, $\left.\mathrm{CDCl}_{3}\right) \delta 0.87(3 \mathrm{H}, \mathrm{t}, \mathrm{J}=7.3 \mathrm{~Hz}), 0.99-1.29(4 \mathrm{H}, \mathrm{m}), 1.29-1.45(1 \mathrm{H}, \mathrm{m}), 1.45-1.70(2 \mathrm{H}, \mathrm{m}), 1.88$ $(1 \mathrm{H}, \mathrm{t}, \mathrm{J}=10.8 \mathrm{~Hz}), 2.30(1 \mathrm{H}, \mathrm{ds} \mathrm{t}, \mathrm{J}=9.6 \mathrm{~Hz}), 2.43(1 \mathrm{H}, \mathrm{t}, \mathrm{J}=12.8 \mathrm{~Hz}), 2.61(1 \mathrm{H}, \mathrm{d}, \mathrm{J}=15.6$ Hz), 2.71-2.96 (3H, m), 2.96-3.21 (4H, m), $3.83(3 \mathrm{H}, \mathrm{s}), 3.86(6 \mathrm{H}, \mathrm{s}), 3.91(3 \mathrm{H}, \mathrm{s}), 4.14(1 \mathrm{H}, \mathrm{d}, \mathrm{J}$ $=14.6 \mathrm{~Hz}), 4.37(1 \mathrm{H}, \mathrm{d}, \mathrm{J}=14.6 \mathrm{~Hz}), 4.61(1 \mathrm{H}, \mathrm{br} \mathrm{d}, \mathrm{J}=11.09 \mathrm{~Hz}), 6.59(2 \mathrm{H}, \mathrm{s}), 6.60(1 \mathrm{H}, \mathrm{s})$, $6.76(1 \mathrm{H}, \mathrm{dd}, \mathrm{J}=4.0,11.0 \mathrm{~Hz}), 6.83(1 \mathrm{H}, \mathrm{s}), 7.16(2 \mathrm{H}, \mathrm{d}, \mathrm{J}=8.4 \mathrm{~Hz}), 7.26(2 \mathrm{H}, \mathrm{d}, \mathrm{J}=8.4 \mathrm{~Hz})$ 
$9.06(1 \mathrm{H}, \mathrm{s}) .{ }^{1} \mathrm{H} \operatorname{NMR}\left(400 \mathrm{MHz}, \mathrm{CD}_{3} \mathrm{OD}\right) \delta 0.87(3 \mathrm{H}, \mathrm{t}, \mathrm{J}=7.5 \mathrm{~Hz}), 0.92-1.13(3 \mathrm{H}, \mathrm{m}) 1.14-$ $1.24(1 \mathrm{H}, \mathrm{m}), 1.25-1.39(1 \mathrm{H}, \mathrm{m}), 1.39-1.63(2 \mathrm{H}, \mathrm{m}), 2.02(1 \mathrm{H}, \mathrm{t}, \mathrm{J}=11.2 \mathrm{~Hz}), 2.26-2.42(2 \mathrm{H}, \mathrm{m})$, 2.51-2.64 (1H, m), 2.69-2.88 (2H, m), 2.91-3.05 (4H, m), $3.13(1 \mathrm{H}, \mathrm{d}, \mathrm{J}=12.3 \mathrm{~Hz}), 3.64(3 \mathrm{H}, \mathrm{s})$, $3.66(3 \mathrm{H}, \mathrm{s}), 3.71(3 \mathrm{H}, \mathrm{s}), 3.72(3 \mathrm{H}, \mathrm{s}), 3.96(1 \mathrm{H}, \mathrm{d}, \mathrm{J}=15.8 \mathrm{~Hz}), 4.32(1 \mathrm{H}, \mathrm{d}, \mathrm{J}=15.8 \mathrm{~Hz}), 4.68$ $(1 \mathrm{H}, \mathrm{dd}, \mathrm{J}=4.8,13.7 \mathrm{~Hz}), 6.54(1 \mathrm{H}, \mathrm{s}), 6.65(1 \mathrm{H}, \mathrm{m}), 6.66(2 \mathrm{H}, \mathrm{m}), 6.75(1 \mathrm{H}, \mathrm{dd}, \mathrm{J}=4.0,11.5$ $\mathrm{Hz}), 6.99(2 \mathrm{H}, \mathrm{d}, \mathrm{J}=8.8 \mathrm{~Hz}), 7.21(2 \mathrm{H}, \mathrm{d}, \mathrm{J}=8.8 \mathrm{~Hz}) 7.25(1 \mathrm{H}, \mathrm{s}) .{ }^{13} \mathrm{C}$ NMR $(100 \mathrm{MHz}$ $\left.\mathrm{CDCl}_{3}\right) \delta 195.9,166.8,148.6,148.3,147.2,147.4,147.2,137.1,136.8,131.8(2 \mathrm{C}), 129.1,127.7$, $126.6,124.3,116.8,111.5,111.3,109.7,108.6,62.8,61.4,61.3,56.2$ (2C), 56.0, 55.9, 52.5, $44.5, \quad 40.7, \quad 40.4, \quad 38.9, \quad 37.9, \quad 29.7, \quad 28.1, \quad 27.3, \quad 23.8, \quad 11.2$. HRESIMS $\mathrm{m} / \mathrm{z} 768.3202$ $\left(\left[\mathrm{C}_{38} \mathrm{H}_{46} \mathrm{BrN}_{3} \mathrm{O}_{5} \mathrm{~S}_{2}+\mathrm{H}\right]^{+}\right.$calcd. 768.2140).

\subsubsection{1-(3-Ethyl-9,10-dimethoxy-1,3,4,6,7,11b-hexahydro-2H-pyrido[2,1-a]isoquinolin-2-yl-} methyl)-6,7-dimethoxy-3,4-dihydro-1 $H$-isoquinoline-2-carbodithioic acid 2-(4-chlorophenyl)-2-oxo-ethyl ester (4e). Yield: $75.3 \%, \mathrm{mp}=99-101{ }^{\circ} \mathrm{C} \quad{ }^{1} \mathrm{H}$ NMR $\left(400 \mathrm{MHz}, \mathrm{CDCl}_{3}\right) \delta$ $0.88(3 \mathrm{H}, \mathrm{t}, \mathrm{J}=7.4 \mathrm{~Hz}), 0.99-1.15(1 \mathrm{H}, \mathrm{m}), 1.16-1.28(2 \mathrm{H}, \mathrm{m}), 1.29-1.42(1 \mathrm{H}, \mathrm{m}), 1.42-1.55(1 \mathrm{H}$, m), 1.56-1.69 (1H, m), $2.03(1 \mathrm{H}, \mathrm{t}, \mathrm{J}=11.2 \mathrm{~Hz}), 2.35-2.52(2 \mathrm{H}, \mathrm{m}), 2.59(1 \mathrm{H}, \mathrm{d}, \mathrm{J}=15.4 \mathrm{~Hz})$, 2.70-2.88 (2H, m), 2.90-3.25 (4H, m), $3.69(3 \mathrm{H}, \mathrm{s}), 3.83(10 \mathrm{H}, \mathrm{s}), 4.65-4.73(2 \mathrm{H}, \mathrm{m}), 4.91(1 \mathrm{H}$, d, J = 16.6 Hz), $6.54(2 \mathrm{H}, \mathrm{s}), 6.59(1 \mathrm{H}, \mathrm{s}), 6.72(1 \mathrm{H}, \mathrm{dd}, \mathrm{J}=3.9,11.2 \mathrm{~Hz}), 6.77(1 \mathrm{H}, \mathrm{s}), 7.38(2 \mathrm{H}$,

$\mathrm{d}, \mathrm{J}=8.5 \mathrm{~Hz}), 7.94(2 \mathrm{H}, \mathrm{d}, \mathrm{J}=8.5 \mathrm{~Hz}) .{ }^{13} \mathrm{C} \mathrm{NMR}\left(100 \mathrm{MHz}, \mathrm{CDCl}_{3}\right) \delta$ 195.5, 192.2, 148.1, $147.9,147.2,140.0,134.5,134.0,130.0,129.7,129.0,128.1,126.3,125.9,124.5,111.5,111.2$ $109.9,109.7,108.7,62.7,61.4,60.2,56.2,56.1,56.0,55.9,52.4, \quad 44.8,44.2,41.4,40.6,38.9$, 37.8, 29.7, 28.1, 23.8, 11.3. HRESIMS $m / z$ 709.3492 $\left(\left[\mathrm{C}_{38} \mathrm{H}_{45} \mathrm{ClN}_{2} \mathrm{O}_{5} \mathrm{~S}_{2}+\mathrm{H}\right]^{+}\right.$calcd. 709.2537). 
3.3.6. 4-\{2-[1-(3-Ethyl-9,10-dimethoxy-1,3,4,6,7,11b-hexahydro-2H-pyrido[2,1-a]isoquinolin-2-ylmethyl)-6,7-dimethoxy-3,4-dihydro- $1 H$-isoquinoline-2-carbothioylsulfanyl]acetylamino\}-benzoic acid ethyl ester (4f). Yield: 51.4\%, $\mathrm{mp}=90-92{ }^{\circ} \mathrm{C} \quad{ }^{1} \mathrm{H}$ NMR $(400$ $\left.\mathrm{MHz}, \mathrm{CDCl}_{3}\right) \delta 0.86(3 \mathrm{H}, \mathrm{t}, \mathrm{J}=7.4 \mathrm{~Hz}), 0.99-1.11(1 \mathrm{H}, \mathrm{m}), 1.12-1.26(3 \mathrm{H}, \mathrm{m}), 1.36(3 \mathrm{H}, \mathrm{t}, \mathrm{J}=$ $7.1 \mathrm{~Hz}), 1.48-1.69(2 \mathrm{H}, \mathrm{m}), 1.89(1 \mathrm{H}, \mathrm{t}, \mathrm{J}=11.1 \mathrm{~Hz}), 2.30(1 \mathrm{H}, \mathrm{t}, \mathrm{J}=9.8 \mathrm{~Hz}), 2.44(1 \mathrm{H}, \mathrm{t}, \mathrm{J}=$ $12.8 \mathrm{~Hz}), 2.59(1 \mathrm{H}, \mathrm{d}, \mathrm{J}=11.8 \mathrm{~Hz}), 2.78-2.94(3 \mathrm{H}, \mathrm{m}), 2.94-3.20(4 \mathrm{H}, \mathrm{m}), 3.83(3 \mathrm{H}, \mathrm{s}), 3.84$ (3H, s), $3.86(3 \mathrm{H}, \mathrm{s}), 3.87(1 \mathrm{H}, \mathrm{br} \mathrm{s}), 3.91(3 \mathrm{H}, \mathrm{s}), 4.19(1 \mathrm{H}, \mathrm{d}, \mathrm{J}=14.6 \mathrm{~Hz}), 4.31(2 \mathrm{H}, \mathrm{q}, \mathrm{J}=7.1$ Hz), $4.38(1 \mathrm{H}, \mathrm{d}, \mathrm{J}=14.6 \mathrm{~Hz}), 4.60(1 \mathrm{H}, \mathrm{br} \mathrm{d}, \mathrm{J}=11.6 \mathrm{~Hz}), 6.58(1 \mathrm{H}, \mathrm{s}), 6.59(1 \mathrm{H}, \mathrm{s}), 6.60(1 \mathrm{H}$, s), $6.75(1 \mathrm{H}, \mathrm{dd}, \mathrm{J}=4.2,11.0 \mathrm{~Hz}), 6.84(1 \mathrm{H}, \mathrm{s}), 7.44(2 \mathrm{H}, \mathrm{d}, \mathrm{J}=8.7 \mathrm{~Hz}), 7.77(2 \mathrm{H}, \mathrm{d}, \mathrm{J}=8.7$ $\mathrm{Hz}), 9.27(1 \mathrm{H}, \mathrm{s}) .{ }^{13} \mathrm{C} \mathrm{NMR}\left(100 \mathrm{MHz}, \mathrm{CDCl}_{3}\right) \delta 195.9,167.1,166.0,148.3,148.1,147.5,147.2$, $141.8,130.6,129.7,129.0,126.6,125.9,125.8,125.7,124.3,118.8,111.5,111.4,109.9,108.6$, $62.8,61.4,61.1,60.8,56.3,56.2,56.0,55.9,52.4,52.0,41.3,40.7,40.1,39.0,38.0,29.7,29.1$, 23.8, 14.4, 11.2. HRESIMS $m / z 762.4441\left(\left[\mathrm{C}_{41} \mathrm{H}_{51} \mathrm{~N}_{3} \mathrm{O}_{7} \mathrm{~S}_{2}+\mathrm{H}\right]^{+}\right.$calcd. 762.3247).

3.3.7. 1-(3-Ethyl-9,10-dimethoxy-1,3,4,6,7,11b-hexahydro-2H-pyrido[2,1-a]isoquinolin-2-ylmethyl)-6,7-dimethoxy-3,4-dihydro-1H-isoquinoline-2-carbodithioic acid 2-(1,3-dioxo-1,3dihydro-isoindol-2-yl)-ethyl ester (4g). Yield: $27.4 \%, \mathrm{mp}=100-102{ }^{\circ} \mathrm{C}{ }^{1} \mathrm{H}$ NMR $(400 \mathrm{MHz}$, $\left.\mathrm{CDCl}_{3}\right) \delta 0.88(3 \mathrm{H}, \mathrm{t}, \mathrm{J}=7.4 \mathrm{~Hz}), 1.04-1.36(4 \mathrm{H}, \mathrm{m}), 1.37-1.52(2 \mathrm{H}, \mathrm{m}), 1.52-1.69(1 \mathrm{H}, \mathrm{m})$, 1.97-2.16 (1H, m), 2.34-2.52 (2H, m), $2.60(1 \mathrm{H}, \mathrm{d}, \mathrm{J}=13.7 \mathrm{~Hz}), 2.67-2.80(1 \mathrm{H}, \mathrm{m}), 2.86-2.98$ $(1 \mathrm{H}, \mathrm{m}), 2.98-3.27(4 \mathrm{H}, \mathrm{m}), 3.62-3.73(3 \mathrm{H}, \mathrm{m}), 3.83(3 \mathrm{H}, \mathrm{s}), 3.84(6 \mathrm{H}, \mathrm{s}), 3.95(3 \mathrm{H}, \mathrm{s}), 3.98-$ 4.17, $(2 \mathrm{H}, \mathrm{m}), 4.61(1 \mathrm{H}, \mathrm{dd}, \mathrm{J}=4.8,13.6 \mathrm{~Hz}), 6.54(1 \mathrm{H}, \mathrm{s}), 6.55(1 \mathrm{H}, \mathrm{s}), 6.58(1 \mathrm{H}, \mathrm{s}), 6.80(1 \mathrm{H}$, dd, J = 3.8, 11.4 Hz), $6.89(1 \mathrm{H}, \mathrm{s}), 7.62-7.69(2 \mathrm{H}, \mathrm{m}), 7.73-7.82(2 \mathrm{H}, \mathrm{m}) .{ }^{13} \mathrm{C} \mathrm{NMR}(100 \mathrm{MHz}$, $\left.\mathrm{CDCl}_{3}\right) \delta 195.9,168.0(2 \mathrm{C}), 148.0,147.8,147.4,147.2,133.9$ (2C), 133.7, 133.0, $132.0(2 \mathrm{C})$ 
129.8 (2C), 124.6, 123.2, 111.3, 111.2, 110.0, 108.8, 62.6, 61.3, 59.5, 56.3, 56.1, 56.0, 55.9, 52.3, 43.6, 40.7, 39.0, 37.4, 36.8, 34.8, 29.7, 29.2, 28.0, 23.8, 11.3. HRESIMS $\mathrm{m} / z$ 730.4174 $\left(\left[\mathrm{C}_{40} \mathrm{H}_{47} \mathrm{~N}_{3} \mathrm{O}_{6} \mathrm{~S}_{2}+\mathrm{H}\right]^{+}\right.$calcd. 730.2985).

\subsection{Biology}

\subsubsection{Cytotoxicity Assay}

\subsubsection{General Information}

The human androgen receptor positive (LNCaP) and negative (PC3 and DU145) prostate cancer cell lines were purchased from the American Type Culture Collection (Manassas, VA). All cells were grown in cell culture flasks in RPMI culture medium with phenol red (GIBCO) supplemented with only $10 \%$ fetal bovine serum, $1 \%$ L-glutamine and $1 \%$ PenicillinStreptomycin. Cells were cultured in a humidified atmosphere of $95 \%$ air and $5 \%$ carbon dioxide at $37{ }^{\circ} \mathrm{C}$. To sub-culture cells for experiments, cells growing as monolayer cultures were released from the tissue culture flasks by treatment with $0.05 \%$ trypson/EDTA. Cell population density was determined with aid of coulter counter (Beckman) and/or hemocytometer. For all the in-vitro experiments, cell-growth was maintained in the log phase and the cells were used while still in this logarithmic growth phase.

\subsubsection{Cytotoxicity assay of emetine derivatives in DU145, PC3 and LNCaP cell lines.}

The fast growing androgen receptor negative PC3 and DU145 were plated at a population density of $2.5 \times 10^{3}$ cells/well while relatively slow growing androgen receptor positive LNCaP cell lines were plated at a density of $6 \times 10^{3}$ cells/well into 96 well tissue culture plates. The cells were incubated for $24 \mathrm{~h}$ before treatment. Compounds were dissolved in $100 \%$ DMSO to give various concentrations which were serially diluted $(0.01 \mu \mathrm{M}$ to $10 \mu \mathrm{M})$ with complete 
RPMI medium to obtain a uniform DMSO concentration of $0.1 \%$ in the medium. Control cells were treated with an equivalent concentration of DMSO. Cells were exposed to the drugs for seven days and MTT (3-[4,5-dimethylthiazol-2-yl]-2,5-diphenyltetrazolium bromide) cell proliferation assay was done to determine the population of viable cells was on the $3 \mathrm{rd}$, $5^{\text {th }}$, and $7^{\text {th }}$, day of treatment to evaluate the cytotoxic effects of drugs and also measure if the control cells were in the logarithmic growth phase. All assays were done in six replicates and repeated at least twice.

\section{REFERENCES}

1. Siegel, R; Ma, J; Zou, Z. Jemal, A Cancer Statistics, 2014. CA-Cancer J.Clin. 2014, 64, 9-29.

2. Acar, O; Esen, T; Lack, N. A. ScientificWorldJOurnal. 2013, 20, 1-8.

3. Basch, E.; Loblaw A.; Oliver, T.K.; Cardicci, M.; Chen, R.C.; Frame, J. N.; Garrels, K et. al. J Clin Oncol 2014, 32, 1-17.

4. Trewartha, D.; Carter, K. Nat. Rev. Drug Discov. 2013, 12, 823-824

5. Akinboye, E. S.; Bakare, O. The Open Nat. Prod. Journal. 2011, 4, 8-15

6. Dimitrijevic, S.; Duncan, R. J. Bioactive and Compatible Polym. 1998, 13, 165-178.

7. Zhou, Y.-D.; Kim, Y.-P.; Mohammed, K. A.; Jones, D. K.; Muhammad, I.; Dunbar, D. C.; Nagle, D. G. J. Nat. Prod. 2005, 68, 947-950.

8. Selassie, C. D.; Hansch, C.; Khwaja, T. A. J. Med. Chem. 1990, 33, 1914-1919.

9. (a) Siddiqui, S.; Firat, D.; Olshin, S. Cancer Chemother. Rep. 1973, 57, 423-428. (b) Panettiere, F.; Coltman, C. A. Jr. Cancer 1971, 27, 835-841. (c) Kane, R. C.; Cohen, M. H.; 
Broder, L. E.; Bull, M. I.; Creaven, P. J.; Fossieck, B. E. Jr. Cancer Chemother Rep. 1975, 59, 1171-1172. (d) Siddiqui, S.; Firat, D.; Olshin, S. Cancer Chemother Rep 1973, 57, 423-428.

(e) Moertel, C. G.; Schutt, A. J.; Hahn, R. G.; Reitemeier, R. J. Cancer Chemother Rep. 1974, 58, 229-232. (f) Street, E. W. Lancer. 1972, 2, 281-282. (g) Mastrangelo, M. J.; Grage, T. B.; Bellet, R. E.; Weiss, A. J. Cancer. 1973, 31, 1170-1175.

10. Boon-Unge, K.; Yu, Q.; Zou, T.; Zhou, A.; Govitrapong, P.; Zhou, J. Chem Biol. 2007, 14, 1386-1392.

11. Möller, M.; Herzer, K.; Wenger, T.; Herr, I.; Wink, M. Oncology Reports. 2007, 18, 737744.

12. Smukste, I.; Bhalala, O.; Persico, M.; Stockwell, B. R. Cancer Cell. 2006, 9, 133-146.

13. Polli, J. W.; Wring, S. A.; Humphreys, J. E.; Huang, L.; Morgan, J. B.; Webster, L. O.; Serabjit-Singh, C. S. J. Pharmacol. Exp. Ther. 2001, 299, 620-628.

14. Pires, M. M.; Hrycyna, C. A.; Chmielewski, J. Biochemistry, 2006, 45, 11695-11702.

15. Akinboye, E.S.; Rosen, M.D.; Denmeade, S.R.; Kwabi-Addo, B. and Bakare, O. J. Med. Chem. 2012, 55(17), 7450-7459.

16. Lee, B.-H.; Bertram, B.; Schmezer, P.; Frank, N.; Wiessler, M. J. Med. Chem. 1994, 37, 3154-3162.

17. Mehta, R. G.; Liu, J.; Constantinou, A.; Thomas, C. F.; Hawthorne, M.; You, M.; Gerhuser, C.; Pezzuto, J. M.; Moon, R. C.; Moriarty, R. M. Carcinogenesis. 1995, 16, 399-404.

18. Gerhauser, C.; You, M.; Liu, J.; Moriarty, R. M.; Hawthorne, M.; Mehta, R. G.; Moon, R. C.; Pezzuto, J. M. Cancer Res. 1997, 57, 272-278.

19. Cao, S.-L.; Feng, Y.-P.; Jiang, Y.-Y.; Liu, S.-Y.; Ding, G.-Y.; Li, R.-T. Bioorg. Med. Chem. Lett. 2005, 15, 1915-1917. 
20. Troconis, M.; Ma, W.; Nichols, D. E.; McLaughlin, J. J. Comput. -Aided Mol. Des. 1998, 12, 411-418. 
Table 1 Cytotoxicity of dithiocarbamate analogs of emetine in androgen receptor positive (LNCaP) and negative (PC3 and DU145) on day 3 of exposure

\begin{tabular}{|l|l|l|l|}
\hline \multicolumn{3}{|c|}{ Cytotoxicity IC $\mathbf{5 0}(\boldsymbol{\mu M})$ on day 3 } \\
\hline Compound & LNCaP & PC3 & DU145 \\
\hline $\mathbf{1}$ & $0.565 \pm 0.012$ & $0.442 \pm 0.036$ & $0.377 \pm 0.018$ \\
\hline $\mathbf{2}$ & $1.966 \pm 0.088$ & $2.535 \pm 0.099$ & $2.741 \pm 0.092$ \\
\hline $\mathbf{4 a}$ & $3.659 \pm 0.044$ & $5.978 \pm 0.168$ & $3.658 \pm 0.053$ \\
\hline $\mathbf{4 b}$ & $4.785 \pm 0.137$ & $8.264 \pm 0.006$ & $3.220 \pm 0.031$ \\
\hline $\mathbf{4 c}$ & $9.217 \pm 0.709$ & $>10.000$ & $>10.000$ \\
\hline $\mathbf{4 d}$ & $5.280 \pm 0.191$ & $3.868 \pm 0.277$ & $5.654 \pm 0.319$ \\
\hline $\mathbf{4 e}$ & $5.721 \pm 0.092$ & $3.594 \pm 0.113$ & $3.170 \pm 0.158$ \\
\hline $\mathbf{4 f}$ & $4.667 \pm 0.132$ & $4.363 \pm 0.084$ & $5.157 \pm 0.101$ \\
\hline $\mathbf{4 g}$ & $3.221 \pm 0.117$ & $3.207 \pm 0.071$ & $3.809 \pm 0.051$ \\
\hline Emetine & $0.037 \pm 0.001$ & $0.035 \pm 0.001$ & $0.033 \pm 0.001$ \\
\hline
\end{tabular}


Table 2 Cytotoxicity of dithiocarbamate analogs of emetine in androgen receptor positive (LNCaP) and negative (PC3 and DU145) on day 5 of exposure

\begin{tabular}{|l|l|l|l|}
\hline \multicolumn{3}{|c|}{ Cytotoxicity IC $50(\mu M)$ on day 5 } \\
\hline Compound & LNCaP & DU145 \\
\hline $\mathbf{1}$ & $0.088 \pm 0.003$ & $0.091 \pm 0.006$ & $0.080 \pm 0.001$ \\
\hline $\mathbf{2}$ & $1.890 \pm 0.092$ & $2.021 \pm 0.049$ & $2.070 \pm 0.103$ \\
\hline 4a & $1.613 \pm 0.066$ & $3.21 \pm 0.117$ & $3.189 \pm 0.078$ \\
\hline 4b & $2.308 \pm 0.174$ & $4.855 \pm 0.153$ & $3.148 \pm 0.007$ \\
\hline 4c & $4.732 \pm 0.352$ & $6.562 \pm 0.913$ & $>10.000$ \\
\hline 4d & $2.189 \pm 0.075$ & $2.768 \pm 0.146$ & $2.796 \pm 0.151$ \\
\hline 4e & $2.312 \pm 0.023$ & $2.700 \pm 0.133$ & $3.197 \pm 0.193$ \\
\hline 4f & $2.717 \pm 0.135$ & $2.706 \pm 0.192$ & $2.898 \pm 0.137$ \\
\hline 4g & $2.801 \pm 0.099$ & $2.770 \pm 0.060$ & $3.575 \pm 0.418$ \\
\hline Emetine & $0.027 \pm 0.003$ & $0.027 \pm 0.002$ & $0.025 \pm 0.001$ \\
\hline & & & \\
\hline & & & \\
\hline
\end{tabular}


Table 3 Cytotoxicity of dithiocarbamate analogs of emetine in androgen receptor positive (LNCaP) and negative (PC3 and DU145) on day 7 of exposure

\begin{tabular}{|l|l|l|l|}
\hline \multicolumn{3}{|c|}{ Cytotoxicity IC } & ( $(\boldsymbol{M M})$ on day 7 \\
\hline Compound & LNCaP & PC3 & DU145 \\
\hline $\mathbf{1}$ & $0.079 \pm 0.003$ & $0.087 \pm 0.003$ & $0.079 \pm 0.003$ \\
\hline $\mathbf{2}$ & $1.312 \pm 0.032$ & $1.560 \pm 0.290$ & $1.980 \pm 0.213$ \\
\hline $\mathbf{4 a}$ & $1.592 \pm 0.014$ & $3.027 \pm 0.160$ & $2.300 \pm 0.067$ \\
\hline $\mathbf{4 b}$ & $1.763 \pm 0.039$ & $4.355 \pm 0.091$ & $2.253 \pm 0.084$ \\
\hline $\mathbf{4 c}$ & $3.390 \pm 0.339$ & $5.201 \pm 0.125$ & $>10.000$ \\
\hline $\mathbf{4 d}$ & $1.698 \pm 0.187$ & $1.507 \pm 0.896$ & $1.603 \pm 0.093$ \\
\hline $\mathbf{4 e}$ & $1.951 \pm 0.068$ & $2.692 \pm 0.145$ & $2.449 \pm 0.162$ \\
\hline $\mathbf{4 f}$ & $1.656 \pm 0.564$ & $1.902 \pm 0.134$ & $2.467 \pm 0.263$ \\
\hline $\mathbf{4 g}$ & $2.303 \pm 0.121$ & $2.378 \pm 0.240$ & $3.050 \pm 0.070$ \\
\hline Emetine & $0.037 \pm 0.001$ & $0.029 \pm 0.003$ & $0.024 \pm 0.001$ \\
\hline
\end{tabular}

